УДК 330

DOI: https://doi.org/10.54929/pmtl-issue2-2021-12

\title{
ПУБЛІЧНЕ УПРАВЛІННЯ У СФЕРІ СОЦІАЛЬНОЇ ПОЛІТИКИ
}

\section{PUBLIC ADMINISTRATION IN THE FIELD OF SOCIAL POLICY}

\author{
Балика Б. О. \\ аспірант кафедри публічного управління та \\ менеджменту органзації \\ Національний університет «Чернігівська Політехніка» \\ ORCID: 0000-0002-8160-8645 \\ Bohdan Balyka \\ Postgraduate student of the Department of Public Administration and \\ organization management \\ Chernihiv Polytechnic National University
}

У статті розглянуто теоретичні аспекти публічного управління соціальною політикою держави. Зокрема, розкрито сутність соціальної політики, їі завдання, об’єкти та суб'єкти. Охарактеризовано методологію фрормування публічного управління соціальної політики, визначено дефрінічію публічного управління, його напрямки реалізації, фуннції, елементи управлінського процесу. Також представлено напрямки оцінки ефрективності, характеристику успішності та проблем публічного управління у сфері соціальної політики. Запропоновано розширити напрямки щодо підвищення рівня ефективності управління, зокрема: боротьба з корупцією, забезпечення міжвідомчої взаємодії та зворотного зв'язку, використання нових технологій у сфрері управління (проектного управління, smart-технологій), формування системи моніторингу управління соціальною політикою та методичного інструментарію оцінки їі ефективності на різних рівнях, а також вдосконалення підготовки фрахівців та постійне підвищення їх кваліфікації. Ключові слова: соціальна держава, управління, публічне управління, соціальна політика, соціальне управління, місцеве самоврядування, оцінка ефективності.

В статье рассмотрены теоретические аспекты публичного управления социальной политикой государства. В частности, раскрыта сущность социальной политики, ее задачи, объекты и субъекты. Охарактеризована методология формирования публичного управления социальной политики, определена дефиниция публичного управления, его направления реализации, фрункции, элементы управленческого процесса. Также представлены направления оценки эфрфективности, характеристика успешности и проблем публичного управления в сфрере социальной политики. Предложены направления повышения уровня эфрфективности управления, в частности: борьба с коррупцией, обеспечение межведомственного взаимодействия и обратной связи, использование новых технологий в сфрере управлений (проектного управления, smart-технологий), формирование системы мониторинга управления социальной политикой и методического инструментария оценки ее эффрективности на разных уровнях, а также усовершенствование подготовки специалистов и постоянное повышение их квалификации. Ключевые слова: социальное государство, управление, публичное управление, социальная политика, социальное управление, местное самоуправление, оценка эфффективности.

The article considers the theoretical aspects of public management of social policy of the state. In particular, the essence of social policy, its tasks, objects and subjects are revealed. The methodology of formation of public management of social policy is characterized, the definition of public management, its directions of realization, functions, elements of administrative process are defined. Areas of evaluation of efficiency, characteristics of success and problems of public administration in the field of social policy are also presented. Directions for improving the level of management efficiency are proposed, in particular: fight against corruption, interdepartmental interaction and feedback, use of new technologies in the field of management (project management, smart technologies), formation of social policy management monitoring system and methodological tools for assessing its effectiveness. at different levels, as well as improving the training of specialists and their continuous training. The formation of a democratic and social state, focused on meeting the social needs of the population, led to the problem of defining the essence of public management of social policy, its characteristics, performance indicators and problematic aspects, as well as recommendations for improving governance. The purpose of this work is a theoretical analysis of the nature and specifics of the effectiveness of public administration in the field of social policy, as well as to identify recommendations for improving its effectiveness. Public management of social policy is implemented in several areas: regulatory regulation, implementation of regulatory institutions, control over the activities of bodies and institutions of the social sphere. The content of management processes, mainly executive and administrative activities, determines the important role of the executive branch in the implementation of the mechanism of state management of the social sphere. The management of social policy performs a range of functions, namely: forecasting, planning, organization of general man- 
agement, operational management and intervention, regulation, accounting and control, performance monitoring. Key words: welfare state, management, public administration, social policy, social management, local self-government, efficiency assessment.

Постановка проблеми. Формування реалізації демократичної та соціальної держави, орієнтованої на задоволення соціальних потреб населення, зумовило постановку проблеми визначення сутності публічного управління соціальною політикою, його характеристики, показників успішності та проблемних аспектів, а також рекомендації щодо підвищення рівня ефрективності управління.

Аналіз останніх досліджень і публікацій. Публічне управління у сфері соціальної політики, давно привертає до себе увагу науковців різних сорер та напрямків. Сучасні західні теоретики, такі як Дж. Бернхем, Д. Белл, Дж. Гелбрейт, М. Уолцер, К. Джон, Д. Кол та інші, бачать в управлінні соціальною політикою силу, здатну позбавити суспільство властивих йому соціальних проблем та підвищити його життєздатність. Вітчизняні дослідники Т. Семигіна, О. Палій, Е. Лібанова, В. Куценко, В. Лобас, О. Скрипник, В. Скуратівський, І. Колосовська, В. Лаврухін, В. Бакуменко, Н. Борецька та інші, у своїх наукових працях розглядають загальні концептуальні засади публічного управління у сорері соціальної політики.

Але по при значну чисельність досліджень присвячених обраній тематиці, досі існує велика кількість проблемних питань, які потребують більш детального розгляду. Зокрема, розгляд дефініції «соціальної політики» в управлінському контексті, а також дослідження шляхів підвищення рівня ефективності публічного управління в сфрері соціальної політики.

Формулювання цілей статті (постановка завдання). Метою даної роботи $є$ теоретичний аналіз сутності та специфріки ефективності публічного управління у сфрері соціальної політики, а також визначення рекомендацій щодо підвищення рівня його ефективності.

Виклад основного матеріалу дослідження. Сучасний світ характеризується глобальними змінами як у політичному, так і в соціальноекономічному житті суспільства, та багато в чому визначається результативністю реформ, направлених на підвищення ефективності функціонування різних інститутів та структур. В Україні, як і в багатьох інших країнах світу, актуальним $\epsilon$ проблеми підвищення якості життя населення. Реформи, що проводяться в нашій країні, спрямовані на створення оптимальної та ефективної системи публічного управління, так як тільки ефективна державна влада здатна створити умови для підвищення рівня та якості життя населення.

Відповідно до Конституції, Україна є соціальною державою (ст. 1), що визначає пріоритетність цієї сфрери життєдіяльності, зокрема і з погляду управління [4]. Реалізація даної конституційної норми передбачає активну діяльність держави, спрямовану на забезпечення високого рівня соціальної захищеності громадян, досягнення соціальної справедливості та солідарності, гармонізації відносин між інститутами державного управління та суспільством та ін. Соціальна держава - це держава, кінцевою метою якого є високий рівень життя населення, сталий розвиток галузей соціальної сорери, підвищення якості громадських послуг, дотримання та розширення прав і свобод людини [2, c. 125].

Вивчення підходів до розуміння соціальної політики дозволяє доцільно та логічно розглядати ії через діяльність держави, спрямовану на регулювання, стабілізацію та розвиток соціальних відносин у суспільстві та визначати сутність соціальної політики через специфіку соціальних відносин, тобто тих відносин, які вона покликана регулювати.

Таким чином, соціальна політика - це система заходів або дій, здійснювана ії суб'єктами (органами державного управління, окремими особами та іншими суспільно-політичними структурами), спрямована на формування соціальної стратегії держави з метою розвитку суспільства, створення суспільно прийнятних соціальних умов для реалізації можливостей та потреб членів суспільства, підвищення рівня та якості їх життя [6, с. 130].

Об'єктом соціальної політики, дослідники називають: соціальні відносини громадян (населення, суспільство, різні соціальні групи та класи, окремі індивіди), а також умови життєзабезпечення людей та їх діяльності. Також існує думка, що об’єктами соціальної політики є відтворення соціальних ресурсів, соціальний розвиток населення, соціальна безпека та достатній рівень добробуту, соціальна структура та потенціал, задоволення людських потреб, соціальні дії, головні напрямки розвитку соціуму, система соціальних нерівностей та основні соціальні проблеми, узгодження інтересів соціальних громад та інші елементи [5, с. 133].

Суб'єктами управління соціальною політикою $є$ конкретні посадові особи, органи державної влади та місцевого самоврядування. Поряд із державними суб'єктами соціальної політики є: державні установи та відомства; органи та структури місцевого самоврядування; недержавні організації та фронди; релігійні, громадські, благодійні та інші організації; комерційний бізнес та комерційні структури; професійні працівники, які займаються розробкою та реалізацією соціальної політики, а також волонтери; громадяни, які беруть участь у групах самодопомоги та у цивільних ініціативах тощо [6, с. 133].

Головне завдання соціальної політики полягає 
в тому, щоб забезпечити кожного громадянина доступним комплексом соціальних благ, задовольняючих його необхідні біологічні, матеріальні, соціальні, духовні потреби.

Публічне управління у сорері соціальної політики може характеризуватись як організаційна діяльність із забезпечення досягнення соціальних цілей та завдань за допомогою певних методів [1, с. 178].

Методологія публічного управління соціальною політикою формується в сучасній Україні під впливом процесів соціокультурної трансформації, яка $є$ комплексним, переважно еволюційним перетворенням суспільства на соціокультурну систему. Комплексність даних перетворень розглядається як трансформаційний процес, який охоплює основні структури та явища системи і тому не зводиться до «реформ згори», а його хід і результат значною мірою залежать від дій масових соціальних груп. Це зумовлює принципову неоднозначність результату. Результатом трансформації може стати як поступальний, прогресивний розвиток суспільства, так і його регрес і навіть деградація, коли внаслідок трансформаційних змін суспільство виявляється відкинутим на кілька рівнів тому у своєму розвитку [7, с. 57].

В цьому сенсі публічне управління можна визначити як систему кооперації державних, муніципальних, некомерційних та змішаних структур, покликану забезпечити задоволення суспільних інтересів та вирішення колективних проблем. Публічне управління, об'єднуючи діяльність державних, муніципальних, неурядових (некомерційних) організацій, фрактично представляє громадськодержавну систему реалізації загальнонаціональних та місцевих інтересів та виробництва суспільних благ.

Публічне управління соціальною політикою реалізується за декількома напрямками: нормативно-правове регулювання, практична реалізація нормативно-правових установ, контроль за діяльністю органів та установ соціальної сфери. Змістовне наповнення управлінських процесів переважно виконавчо-розпорядницькою діяльністю, що зумовлює вагому роль виконавчої влади в реалізації механізму державного управління соціальною сферою.

Також управління соціальною політикою виконує цілий комплекс функцій, а саме: прогнозування, планування, організація загального керівництва, оперативне розпорядження та втручання, регулювання, облік та контроль, перевірки виконання.

Управлінський процес є циклічним, і крім цілепокладання він включає також: планування, пов'язане з розробкою планів соціального розвитку та соціального проектування; організацію дій учасників спільної діяльності, розподіл між ними фрункцій, завдань, забезпечення виконання прийнятих планів або рішень; координацію діяльності взаємодіючих суб'єктів; стимулювання людей шляхом формування відповідних мотивів та установок, забезпечення контролю за ходом реалізації прийнятої постанови або іншого управлінського документа [5, с. 32].

Оцінка ефективності публічного управління у сфрері соціальної політики повинна провадиться на основі наступних підходів: оцінки на основі показників соціально-економічного розвитку, на які суб'єкти соціальної політики безпосередньо впливають; оцінка на основі показників, що безпосередньо пов'язані з виконанням різних повноважень на національному, регіональному та місцевому рівнях; оцінка проведення реформ; оцінка з урахуванням показників ефективності витрачання бюджетних коштів; оцінка ефективності діяльності влади населенням на основі опитувальних, соціологічних показників [3, с. 76].

Успішність реалізації соціальної політики, досягнення в результаті соціальної справедливості в суспільстві залежать не тільки від продуманості параметрів та здійсненності в конкретних умовах концепції публічного управління, а й від послідовної реалізації соціальної політики в умовах децентралізації, від скоординованості дій влади (національного, регіонального, місцевого рівнях), що здійснюють управління цією сферою.

Проблема розвитку соціальної політики, обумовлена постійним пошуком оптимального балансу між ефективним виконанням державою своєї соціальної функції, що забезпечує гідний рівень життя громадян, якісне задоволення основних соціальних потреб та зниження соціального тягаря держави в умовах нестабільної економічної ситуації. Знаходження компромісного рішення, що відповідає і публічним інтересам держави (скорочення фрінансових витрат), і зацікавленості окремих осіб (одержання якісних послуг у повному обсязі, гарантованих Конституцією), ускладнюється часто не тільки антагоністичною спрямованістю цих інтересів, а й труднощами, пов'язаними з неготовністю суспільства до кардинальних перетворень у цій сорері, недостатньою розвиненістю інституційних елементів суспільства, що залучаються до модернізаційних процесів. Проведення на сучасному етапі модернізації різних складових соціальної політики обумовлене як необхідністю вибудовування ефрективнішої соціально-економічної системи суспільства та заміни застарілих малоефективних засобів управління інституційними елементами. Здійснювані перетворення спрямовані на створення умов для фоормування та розвитку конкурентоспроможного суспільства, що має реальний потенціал для досягнення високих показників добробуту своїх громадян та забезпечення гідного рівня життя [3, с. 83]. 
Отже, слід зазначити, що підвищення ефективності діяльності державних органів управління $\epsilon$ складним, комплексним завданням, що вимагає концентрації зусиль багатьох структур суспільства, відкритості влади до змін, готовності населення до діалогу із владою. Все це вимагає переосмислення значення ролі та фрункцій держави, сутності іiї взаємин із суспільством. Поспішні та непродумані рішення можуть призвести до значних економічних та соціальних втрат, не кажучи вже про те, що про успішність діяльності органів державної влади не може бути й мови.

Напрямками, щодо підвищення рівня ефективності публічного управління в соціальній політиці, можуть бути: боротьба з корупцією і підвищення рівня прозорості підготовки та прийняття рішень, законодавчих актів, а також забезпечення прозорості та неупередженості підбору кадрів.

Необхідним є забезпечення і вдосконалення зворотного зв'язку діалогу суспільства та держави, визначення його реальних проблем та потреб. Організація ефрективної взаємодії між державою, бізнесом, недержавним сектором у реалізації соціальної політики.

Важливим $€$ підвищення ефрективності міжвідомчої взаємодії, взаємодії органів влади національного, регіонального та муніципального рівня. Також необхідним $є$ розробка ефеективної системи моніторингу управління соціальною політикою та методичного інструментарію оцінки ії̈ ефективності на різних рівнях.
Під час управління соціальною політикою варто використовувати передові технології організації діяльності в державному секторі, нові методи та кращі практики реалізації державних функцій та надання послуг (проектне управління, Smart-технології). Також важливим $є$ вдосконалення підготовки кадрів для роботи у сфрері публічного управління соціальною політикою та постійне підвищення їх кваліфрікації

Висновки 3 цього дослідження і перспективи подальших розвідок у даному напрямку. Таким чином, підвищення рівня ефрективності діяльності органів публічного управління соціальною політикою $є$ цілим комплексом складних взаємопов'язаних процесів, що включають не тільки організаційні та структурні зміни у системі управління, а й удосконалення механізмів здійснення повноважень та функцій державного управління. При цьому вдосконалення системи державного управління має супроводжуватися не тільки зміцненням владних повноважень, а й одночасним дотриманням суспільних інтересів, забезпеченням прозорості діяльності органів та установ державної влади, а також протидією корупції. Важливим механізмом забезпечення ефективності діяльності державного управління виступає вдосконалення законодавства.

Дане дослідження не вичерпує усіх аспектів проблеми. Подальшим перспективним напрямком дослідження $є$ детальне вивчення оцінки ефективності публічного управління в сфрері соціальної політики.

\section{БІБЛІОГРАФІЧНИЙ СПИСОК:}

1. Балтачеєва, Н. Б. Методологічні аспекти розробки структури механізму формування і реалізації соціальної політики в сучасних умовах. ВІСНИК Донбаської державної машинобудівної академії, 2012. 2 (27), 178-183.

2. Скуратівський В., Трощинський В., Ситник П. Державна політика в соціогуманітарній сфері: підручник. Видавництво НАДУ. 2007.

3. Скуратівський В., Трощинський В., Ситник П., Кравченко М., Петрос О. Управління соціальним і гуманітарним розвитком. НАДУ. 2009.

4. Конституція України, № 254к/96-ВР (2020) (Україна). https://zakon.rada.gov.ua/laws/show/254к/96-вp\#Text

5. Ткачова О. Ефективність державного управління: поняття та підходи до оцінювання. Вісник Національної академії державного управління, 2013. 2 (6), 30-37.

6. Волгина Н. (Ред.). Государственная и муниципальная социальная политика. Курс лекций. КНОРУС. 2018.

7. Чернов С., Гайдученко С. Текст лекцій з дисципліни «Публічне адміністрування». ХНУМГ. 2014.

\section{REFERENCES:}

1. Baltacheieva, N. B. (2012). Metodolohichni aspekty rozrobky struktury mekhanizmu formuvannia i realizatsii sotsialnoi polityky v suchasnykh umovakh. VISNYK Donbaskoi derzhavnoi mashynobudivnoi akademii, (2 (27)), 178-183. (in Ukrainian).

2. Skurativskyi, V., Troshchynskyi, V., \& Sytnyk, P. (2007). Derzhavna polityka v sotsiohumanitarnii sferi: pidruchnyk. Vydavnytstvo NADU. (in Ukrainian).

3. Skurativskyi, V., Troshchynskyi, V., Sytnyk, P., Kravchenko, M., \& Petros O.. (2009). Upravlinnia sotsialnym i humanitarnym rozvytkom. NADU. (in Ukrainian).

4. Konstytutsiia Ukrainy, № 254k/96-VR (2020) (Ukraina). https://zakon.rada.gov.ua/laws/show/254k/96-vr\#Text (in Ukrainian).

5. Tkachova, O. (2013). Efektyvnist derzhavnoho upravlinnia: poniattia ta pidkhody do otsiniuvannia. Visnyk Natsionalnoi akademii derzhavnoho upravlinnia, (2 (6)), 30-37. (in Ukrainian).

6. Volhyna, N. (Red.). (2018). Hosudarstvennaia y munytsypalnaia sotsyalnaia polytyka. Kurs lektsyi. KNORUS. (in Ukrainian).

7. Chernov, C., \& Haiduchenko, S.. (2014). Tekst lektsii z dystsypliny «Publichne administruvannia». KhNUMH. (in Ukrainian). 